\title{
INVESTIGATING BOARD DIVERSITY IN SOUTH AFRICA
}

\author{
Nadia Mans-Kemp* \\ Stellenbosch University \\ nadiamans@sun.ac.za
}

Received: April 2014

\author{
Suzette Viviers" \\ Stellenbosch University \\ sviviers@sun.ac.za
}

Accepted: December 2014

\begin{abstract}
The issue of board diversity has been widely debated. Given the lack of conclusive empirical evidence, this study investigated the relationship between gender and race board diversity and the financial performance of South African companies. The sample covered 1542 annual observations over the period 2002 to 2012. The percentage of female and black directors of companies listed on the Johannesburg Stock Exchange increased significantly over the research period. Board diversity differed considerably across industries. A statistically significant positive relationship existed between the percentage of both female and black directors and earnings per share. In contrast, a statistically significant negative relationship was found between the percentage of both female and black directors and total shareholder return. Given the lack of a clear business case, the question arises as to how board diversity on the JSE can be encouraged. The researchers recommend that more attention should be given to the development and mentoring of diverse board candidates.
\end{abstract}

Keywords

Board diversity, Gender diversity, Race diversity, Accounting-based financial performance, Market-based financial performance

*Dr N Mans-Kemp is a lecturer in the Department of Business Management, Stellenbosch University, South Africa.

\#Prof S Viviers is a professor in the Department of Business Management, Stellenbosch University, South Africa. 


\section{INTRODUCTION}

I know there is strength in the differences between us. I know there is comfort where we overlap.

This quote by the poet Ani Difranco (in Bromley, 2012) holds true in various contexts. In its broadest sense, diversity refers to 'human groupings based on race, gender, ethnicity, age, knowledge, education, professional background, values, perception, affection and certain personality characteristics' (Erhardt, Werbel \& Shrader, 2003:102). This broad definition indicates that diversity goes beyond the observable demographic features of an individual, by also including non-observable (cognitive) features such as leadership ability and communication skills.

Several authors have illustrated that the diversity of a company's board of directors aids creativity and innovation, which can translate into improved financial performance (European Commission, 2012; Smith, Smith \& Verner, 2006; Erhardt, et al., 2003). Others scholars hold on to the notion of ex unitate vires (strength from unity) and argue that diversity could lead to conflict. Such conflict can result in slower decision-making and hence weaker financial performance (Adams \& Ferreira, 2009).

Due to discriminatory policies in South Africa, the majority of the board members of companies listed on the Johannesburg Stock Exchange (JSE) pre-1994 were middle aged, white males. Apartheid legislation, such as the Labour Relations Act (No. 28 of 1956), prohibited blacks from holding managerial positions and directorships within South African companies (Rushin, 2006). Black is a generic term referring to Africans, coloureds, Indians and Chinese (Government Gazette, 2004). After democracy was established in 1994, many foreign investors returned to South Africa. In exchange for their capital, they demanded reform in both corporate structures and corporate governance practices (Abdo \& Fisher, 2007). Voluntary initiatives to promote change (most notably the King Reports on corporate governance) and new legislation were designed to create a level playing field for all South Africans in the corporate environment. New legislation included the Labour Relations Act (No. 66 of 1995), the Employment Equity Act (No. 55 of 1998) and the Broad-Based Black Economic Empowerment (B-BBEE) Act (No. 53 of 2003).

Despite these initiatives, little has changed over the past two decades. Despite making up $51.3 \%$ of all South Africans and $43 \%$ of the economically active population, women are still severely under-represented as senior managers and directors (Mid-year population estimates 2013, 2013; The Inoxico Director Singularity Index, 2013). The situation is even worse as regards the representation of blacks in these corporate positions. Nyirenda (2010) claims that there have been many 'token' board appointments in South Africa over the past two decades. Tokenism refers to the process of appointing individuals into positions where they are ineffective, just to meet race and gender compliance targets (Nyirenda, 2010). This situation is clearly not optimal for either the individuals or the companies concerned.

A reason for the lack of board diversity in South Africa could be attributed to the lack of suitably educated candidates who can serve as directors (South African History Online, 2014). The situation is, however, likely to change in future, as there is now a relatively small gap between male and female university graduates entering the local labour market (Scholtz, 2014). A recent study by the Department of Higher Education and Training also reported that the racial composition of students across South African universities in 2013 reflected the demographics of the country (Mtshali, 2013). Furthermore, in November 2013, the Women Empowerment and 
Gender Equality Bill was tabled in Parliament. This bill calls for $50 \%$ participation by women in decision-making structures (including boards) of designated public and private bodies.

Critics of the proposed legislation question whether the bill will have any teeth (Scholtz, 2014). The researchers are also quite sceptical as to the effectiveness of the proposed bill (and existing legislation) to bring about any real change. As long ago as 402BC the Greek philosopher Plato observed that "good people (companies) do not need laws to tell them to act responsibly, while bad people (companies) always find a way around the law" (in Parsons, 2004). Perhaps a more powerful driver of corporate change would be to demonstrate that a specific corporate action can be profitable. Numerous academic studies have endeavoured to establish a business case for corporate actions such as corporate social responsibility and sustainable development (Smith, Smith \& Verner, 2006; Dobbin \& Jung, 2011).

\section{PROBLEM STATEMENT AND RESEARCH OBJECTIVES}

Companies generally institute change only once management is convinced of the financial benefits associated with a proposed action (Robinson \& Dechant, 1997). At present, no clear business case exists for increasing the diversity of a company's board. Given inconclusive international evidence and a paucity of research in South Africa, the researchers set out to investigate the relationship between board diversity and financial performance in more detail. If a sound business case can be made for board diversity in South Africa, it is likely that progress could be made in transforming local boards.

To give effect to the problem statement, three research objectives were formulated. In the first instance the researchers set out to provide an appropriate definition of board diversity in the South African context. The second research objective centred on an analysis of the relevant literature on the relationship between board diversity and financial performance, while the third research objective entailed an empirical analysis of this relationship.

The role of the directorate and concepts such as board gender diversity and board race diversity will be discussed in the following sections. These two elements of board diversity have been selected given their relevance in the South African context. A brief summary of financial performance measurement and its relationship to board diversity are also presented. Subsequently, the population, sample and methods to collect and analyse secondary data are described. The final section of the article deals with the findings and recommendations of the study.

\section{LITERATURE REVIEW}

A company's directorate represents the focal point of its decision-control system (Institute of Directors in Southern Africa, 2002; Fama \& Jensen, 1983). Over the years, the board's role has changed from merely serving as a legal requirement to being responsible for the company's direction and ultimately its corporate success (Naidoo, 2009; Van der Walt \& Ingley, 2003). The board also forms a fundamental element of the company's corporate governance system. The second and third King Reports recommend that the majority of the board should consist of nonexecutive directors (Institute of Directors in Southern Africa, 2009; 2002). Non-executive means that the board member is not involved in the day-to-day running of the firm. Executive directors, on the other hand, are those involved in the daily management of the firm and are 
thus full-time, paid employees (Wixley \& Everingham, 2005). The second King Report also introduced the notion of board diversity and recommended that no single block of individuals (for example white men) should dominate the board (Institute of Directors in Southern Africa, 2002).

A diverse board thus consists of a group of non-homogeneous individuals. Huse (2007) claims that board diversity can increase board independence. He argues that individuals with different gender, race, ethnicity and/or professional backgrounds tend to ask questions that are not usually addressed by directors who have a more 'traditional' background. In this sense, 'traditional' refers to white males in the later stage of their careers. Increased questioning could lead to higher-order problem solving and ultimately to a stronger competitive advantage (Stephenson, 2004; Watson, Kumar \& Michaelsen, 1993). A more diverse board is also considered to be a better monitoring mechanism of managers' actions than a less diverse board (Carter, D'Souza, Simkins \& Simpson, 2010).

There is, however, also a downside to diversity. Research suggests that diverse boards are more likely to experience communication and coordination difficulties than homogeneous boards. Diverse boards also need more time for preparation before and discussions during board meetings (Huse, 2007; Earley \& Mosakowski, 2000; Murray, 1989).

\subsection{Board diversity in terms of gender}

Board gender diversity can be described as the representation of female directors on corporate boards (Campbell \& Minguez-Vera, 2008; Dutta \& Bose, 2007). Gender representation in boardrooms varies widely across countries. Scandinavian countries such as Norway, Sweden and Finland have a fairly large representation of women on boards, often in excess of $20 \%$ (Women on boards: a statistical review by country, region, sector and market index, 2009). This is mainly due to gender equality laws that have been promulgated in these countries in recent years. Depending on the total number of board members, a company in Norway, for example, may be required to have between $33 \%$ and $50 \%$ female directors. In contrast to Scandinavian countries, women represent less than $1 \%$ of the total board directorships in Japan. Research by the Businesswomen's Association of South Africa shows that in 2011, the number of female directorships in JSE-listed companies and state-owned enterprises equalled approximately $15 \%$ (Natsan, 2012). This percentage surpasses that of most other emerging countries (Women on boards: a statistical review by country, region, sector and market index, 2009).

In many companies and industries in the world, the proverbial glass ceiling, which can limit females from reaching the top corporate leadership positions, is still pervasive (Pappaya, 2007; Grobler, Wärnich, Carrell, Elbert \& Hatfield, 2006; Mathur-Helm, 2006). Carter et al. (2010) argue that competent women deserve opportunities to serve on boards, as they bring human capital, external networks and other important characteristics to the boardroom. Research shows that female directors make a positive contribution to the board's working style in that preparation increases and involvement improves (Carter et al., 2010; Adams \& Ferreira, 2009; Huse, 2007). Women are said to ask more discerning questions and have a better understanding of the marketplace (Robinson \& Dechant, 1997). By matching the diversity of directors to that of the customers and employees, permeability along with creativity and innovation can increase (Wachudi \& Mboya, 2009; Stephenson, 2004).

Not all researchers are optimistic about the impact of board gender diversity. Lau and Murringham (1998), for example, argued that increased female participation results in 
unnecessarily high levels of gender-based conflict. Other studies found that, although decisions made by a more gender diverse board were of a higher quality, the slower process of decisionmaking had an adverse effect on the firm's financial performance (Huse, 2007; Jianakoplos \& Bernasek, 1998). Adams and Ferreira (2009) and Campbell and Mínguez-Vera, (2008) caution that, if companies are well-governed, mandatory gender quotas and excessive board monitoring can decrease shareholder value.

\subsection{Board diversity in terms of race}

Given South Africa's history, there is immense pressure on companies, particularly listed companies, to transform their demographics at all levels (Nyirenda, 2010). Race is thus an important aspect of the board diversity debate in South Africa. Business Unity South Africa (2011) conducted a survey on the demographics of the boards of all companies listed on the main board of the JSE as at 23 March 2011. The survey revealed that $9.5 \%$ of executive directors were black and $27.6 \%$ of directors were black non-executive directors.

According to Trautman (2008), firms with racially diversified management teams are likely to consider more opportunities and generate more ideas to create a competitive advantage. Furthermore, blacks are considered to have different life experiences than whites. They thus bring different perspectives and concerns to the boardroom, which allows the directorate to consider a wider range of solutions to corporate issues. Race diversity can furthermore increase innovation by expanding access to social and information networks (Miller \& Triana, 2009). In a study on the banking industry in the United States of America (USA), Orlando (2000) showed that within the proper context, racial and cultural diversity can contribute to a firm's competitive advantage. In contrast, Dobbin and Jung (2011) highlighted the negative consequences associated with race and ethnic diversity, the most prominent of which is group conflict. They show that social clashes interfere with cooperation and could thus lead to lower financial performance. Racial diversity can also increase the risk of emotional conflict, frustration and negative feelings among directors (Pelled, Eisenhardt \& Xin, 1999).

With the exception of Nyirenda (2010), very little academic research has been conducted on the racial distribution of directors in South Africa.

\subsection{Measuring financial performance}

Given that the board plays a key role in maximising shareholder wealth (Hart \& Milstein, 2002; Martin, Petty \& Wallace, 2009), several studies have investigated the relationship between board composition and financial performance. In most of these studies, financial performance was measured in terms of accounting-based measures. These measures reflect a company's past performance as published in its annual report(s). Accounting-based measures typically include profitability ratios such as return on assets (ROA) and return on equity (ROE).

In contrast, share market data is used as the primary source to determine market-based performance measures. These measures are used to evaluate investors' perceptions of a firm's share price performance and market risks (Brigham \& Houston, 2012; Moyer, McGuigan \& Kretlow, 2009). Total shareholder return (TSR) is a pure market-based measure, in that it refers to the return that a shareholder earns over a specific time period. The measure includes the capital gain (or loss) and dividends received during the considered period (Monks \& Lajoux, 2011). Tobin's $\rho$ is a hybrid market-based measure in that it includes both accounting data and data based on the company's share price (Gross, 2007). 
Some researchers regard market-based measures as superior to accounting-based measures (Carton \& Hofer, 2006). Market-based performance measures are preferred, as they include the value created by both the implementation of existing opportunities, as well as the risk-adjusted expected value of future opportunities. Accounting-based measures are subject to managerial manipulation, while share prices (in a well-regulated market) are not subject to manipulation. If it is assumed that markets are relatively efficient, then market-based measures are expected to quickly reflect announcements such as appointing a woman or black person to a company's board (Mulsow, 2011). Finally, accounting-based measures reflect performance only once or twice annually, whereas market-based measures are available on a daily basis (Gross, 2007). Despite the static and backward-looking nature of accounting-based measures, they are often used by financial management researchers.

\subsection{The relationship between board diversity and financial performance}

Contradictory, non-conclusive evidence exists on the board diversity business case. For example, using the largest 2500 Danish firms over the period 1993 to 2001, Smith et al. (2006) analysed whether the proportion of women in top management positions affected firm performance (as measured by inter alia the gross profit margin, operating profit margin and net profit margin). They found that this was indeed the case, even after controlling for firm characteristics and the direction of causality. More specifically, a significant positive relationship was found between the gross profit margin and female board representation. A positive relationship between gender diversity and firm value (as measured in terms of Tobin's Q) was also reported by Campbell and Mínguez-Vera (2008). Arguden's (2012) analysis of FTSElisted boards revealed that both operational performance and share prices were higher for firms with more than $20 \%$ female board representation compared to companies with lower female representation. Taking both gender and race diversity into account, Erhardt et al. (2003) found a significant positive relationship between board diversity and accounting profit (as measured by ROA). This study involved 127 large USA firms over the period 1993 to 1998.

Other researchers, such as Dutta and Bose (2007), reported conflicting results on the relationship between gender diversity and the profitability ratios ROA and ROE. No association was found between female board representation and ROA in a study conducted by Dobbin and Jung (2011) on 432 USA firms over the period 1997 to 2006. In the same study, gender diversity showed a negative relationship with share price performance. The authors explained the finding by stating that 'it is possible that some institutional investors sell shares of more diverse boards, not based on the companies' performance, but because these investors are biased against women'. Adams and Ferreira (2009) also established a significant negative relationship between gender diversity and financial performance (as measured in terms of ROA and Tobin's Q). The same applies to Rose (2007), who reported a negative association between gender diversity and Tobin's $Q$.

Given the inconclusive evidence on the relationship between board diversity (in terms of gender and race) and various financial performance measures, the alternative hypothesis of this study states that there is a relationship between board diversity and the financial performance of a sample of JSE-listed companies. The following sub-hypotheses were postulated as: 
$\mathrm{H}_{1 \mathrm{a}} \quad$ There is a relationship between board gender diversity and financial performance as measured in terms of accounting-based performance measures.

$\mathrm{H}_{1 \mathrm{~b}} \quad$ There is a relationship between board gender diversity and financial performance as measured in terms of market-based performance measures.

$\mathrm{H}_{2 \mathrm{a}} \quad$ There is a relationship between board race diversity and financial performance as measured in terms of accounting-based performance measures.

$\mathrm{H}_{2 \mathrm{~b}} \quad$ There is a relationship between board race diversity and financial performance as measured in terms of market-based performance measures.

\section{RESEARCH DESIGN AND METHODOLOGY}

In this section, attention is given to the construction of the sample, as well as the methods used to collect and analyse secondary data. The population consisted of the companies listed on the JSE over the period 2002 to 2012 (see TABLE 1). This period was characterised by the publication of the second King Report on corporate governance in 2002 and the third King Report in 2009. This period furthermore includes a cycle of strong economic growth (2002-2006), followed by the global financial crisis (2007-2009) and a recovery period (2010-2012) (South African Reserve Bank, 2013; Bureau for Economic Research, 2009).

TABLE 1: Details of the population and sample utilised in this study

\begin{tabular}{ccc} 
Year & Population* & Sample \\
2002 & 451 & 140 \\
2003 & 411 & 150 \\
2004 & 389 & 142 \\
2005 & 373 & 138 \\
2006 & 389 & 131 \\
2007 & 411 & 127 \\
2008 & 411 & 142 \\
2009 & 398 & 144 \\
2010 & 397 & 140 \\
2011 & 395 & 145 \\
2012 & 387 & 143 \\
\hline
\end{tabular}

Source: Authors' compilation

* Data sourced from the World Federation of Exchanges (2014)

The sample was constructed in three phases. In phase 1 , the following criteria were employed to identify suitable companies: 
- A company had to be listed in one of the following JSE industries: health care, consumer goods, consumer services, technology, telecommunications and industrials. No companies were listed in the utilities industry during the research period. Companies listed in the oil and gas, basic materials and financials industries were excluded from the sample as their financial statements differ from those companies listed in the considered industries.

- In order to determine whether a firm was listed in one of the considered industries, both the FTSE global classification system (used from 1 June 2002 to 31 December 2005) and the industry classification benchmark (employed since 1 January 2006) were considered (Johannesburg Stock Exchange, 2009).

- Companies that delisted from the JSE during the research period were included for the specific years during which they had been listed. This was done to avoid survivorship bias.

The application of these criteria resulted in 1751 annual observations. In the second phase, annual statements were scrutinised to identify the gender and race of each board member of each company. In instances where the gender and/or race of directors were not disclosed in the annual report, an Internet search was undertaken. Companies' websites and other websites such as Who's Who in South Africa and Linkedin were instrumental in this regard. To ensure consistency, a director had to be a board member at year-end.

Only companies where both the gender and race of all the directors could be identified for a particular year were included in the sample. The percentage of female and black directors could thus be compared on an annual basis. A total of 126 annual observations were excluded due to incomplete gender and race data. More than two-thirds of companies (77.14\%) identified in phase 1 failed to disclose full details on the gender and race of their directors. This number steadily decreased over time, indicating greater transparency in corporate reporting. A mere $16.78 \%$ of companies failed to report the gender and race details of their directors in 2012.

In the third phase, the sample was further reduced due to the lack of data available on the chosen financial performance measures on the McGregor BFA database (2014). A number of observations were also deleted due to outliers in the financial data. The final sample thus covered 1542 annual observations. Details on the gender, race and status (executive versus non-executive) of 14403 directorships were available for the final sample.

From the literature review, it was evident that previous researchers mainly focused on ROA and Tobin's $\rho$ as measures of financial performance. In this article, a broader approach was taken by evaluating four accounting-based measures (net profit margin, ROE, ROA and earnings per share) and three market-based measures, namely total shareholder return, market value added and dividend yield. The equations used to calculate the respective ratios are set out below (McGregor BFA, 2014):

$$
\begin{gathered}
\text { Net profit margin }(\text { NPM })=\frac{\text { Profit after taxation }}{\text { Turnover }} \times 100 \\
\text { Return on equity (ROE) }=\frac{\text { Profit after taxation }}{\text { Book value of ordinary shareholders' equity }} \times 100
\end{gathered}
$$

Return on assets $(\mathrm{ROA})=\frac{\text { Profit before interest and tax }- \text { total profits of extraordinary nature }- \text { tax }}{\text { Total assets }} \times 100$ 
JSE-listed companies are required to report their headline earnings per share (HEPS). This measure consists of the basic EPS (as defined by the accounting standard IAS 33; indicated in Equation 4), excluding certain items. The equation for the basic EPS ratio is (International Financial Reporting Standards, 2012; South African Institute for Chartered Accountants, 2009):

$$
\text { Basic EPS }=\frac{\text { Profit or loss attributable to ordinary shareholders of the parent firm }}{\text { Weighted average number of ordinary shares issued }}
$$

Excluded items include separately identifiable re-measurements, net of related (current and deferred) tax and related non-controlling interest, other than re-measurements specifically included. A re-measurement is an amount acknowledged in a profit or loss relating to any change in the book value of a liability or asset that arises after the initial recognition of the liability or asset (International Financial Reporting Standards, 2012; South African Institute for Chartered Accountants, 2009). The standardised EPS ratios provided by McGregor BFA (2014) were determined according to the HEPS guidelines.

$$
\text { Total shareholder return }(\mathrm{TSR})=100 \times\left(\frac{P_{n}+\left(\sum_{t=0}^{n-1} \frac{D_{t}}{K} \times P_{t}\right)}{P_{0}}\right)-1
$$

Where:

$P_{n} \quad=$ the share price at year end

$P_{0} \quad$ = the share price at the beginning of the year

$P_{t} \quad=$ the share price at time $t$

$n \quad=$ the number of intervals in the period of calculations

$D_{t} \quad$ = the dividend yield at time $t$ (the published dividend per share was used)

$K \quad=1$ (for annual calculations)

Market value added (MVA) $=\frac{\text { Market value of equity }+ \text { interest bearing debt }}{\text { Total capital at book value }}$

$$
\text { Dividend yield (DY) }=\frac{\frac{\text { Ordinary dividend }}{\text { Number of ordinary shares in issue at year end }}}{\frac{\text { Share prices at financial year end }}{100}} \times 100
$$

Tobin's $\rho$ can be used to demonstrate how a firm's shares are valued relative to the property, plant (at market values), equipment and inventory (at replacement cost). Critics of this ratio argue that Tobin's $\rho$ often exaggerates performance, as replacement costs are underestimated. Furthermore, there is a lack of evidence that this ratio can be effectively used over a short study period (Chorafas, 2005). Given criticism of Tobin's $Q$, a decision was taken not to use this measure in this study.

Standardised financial ratios were sourced from the McGregor BFA database (2014) on an annual basis. The data downloaded from this computerised database was scrutinised to ensure the accuracy and dependability of the data. Basic descriptive statistics were used to evaluate the trends in female and black board representation over time. An overall board diversity score was furthermore computed for every company on an annual basis (TABLE 2). 
TABLE 2: Board diversity score ${ }^{(a)}$

\begin{tabular}{llc}
\hline \multicolumn{1}{c}{ Classification } & \multicolumn{1}{c}{ Description } & Code \\
\hline Poor & The percentages of female and black directors are both less than $33.33 \%$. & 1 \\
Average & $\begin{array}{l}\text { Either the percentage of female or percentage of black directors is greater } \\
\text { than } 33.33 \% .\end{array}$ & 2 \\
& $\begin{array}{l}\text { The percentages of female and black directors are both greater than } \\
\text { Good }\end{array}$ & $33.33 \%$.
\end{tabular}

Source: Authors' compilation

(a) In 2007, the government set interim targets of $50 \%$ for female and black board members and executive directors to be achieved by 2017 (Ferreira \& De Villiers, 2011). Given that the research period ended in 2012, target percentages of 33.33\% were used in this study to indicate the level of board diversity representation.

A mixed model repeated measures ANOVA was used to determine whether mean scores for gender and race differed significantly from one year to the next, as expected. A one-way ANOVA was also use based on the expectation that female and black board representation differed across industries. The research hypotheses were tested by using two regression techniques that are commonly used to analyse panel data, namely fixed effects and random effects (Hassett \& Paavilainen-Mäntymäki, 2013; De Jager, 2008). The fixed effects model can be used to study the causes of changes within an observed firm (Kohler \& Kreuter, 2005), while the random effects model allows for the inclusion of time-invariant variables (Dwyer, Gill \& Seetaram, 2012). In this study, the Breusch-Pagan test was used to test for heteroscedasticity (Kacapyr, 2011; Hayes \& Cai, 2007). Adjustments for heteroscedasticity were made where applicable.

\section{EMPIRICAL FINDINGS}

In the following section, the findings presented describe the gender and race of directors in the sample, the board diversity score and the board diversity across industries.

\subsection{Descriptive statistics: female directors}

As indicated in FIGURE 1 and TABLE 3 , the percentage of women on boards increased significantly over the research period $(\mathrm{F}=43.9, p<.001)$.

The average percentage of female directors in this study $(11.81 \%)$ is slightly lower than that reported by the Businesswomen's Association of South Africa (14.6\% in 2011) (Natsan, 2012) and could be due to the exclusion of two large industries from the sample (basic materials and financials). In 2002, black women represented half of all female directors (50.68\%) considered in this study. This figure increased to more than two-thirds (76.89\%) in 2012. Nyirenda (2010) likewise found that the majority of female directors of JSE-listed companies are black. As indicated in TABLE 3, most female directors are NEDs.

The growing number of black NEDs over the research period corresponds with research done by Nyirenda (2010) who found that most non-executive directors in South African businesses are females. 


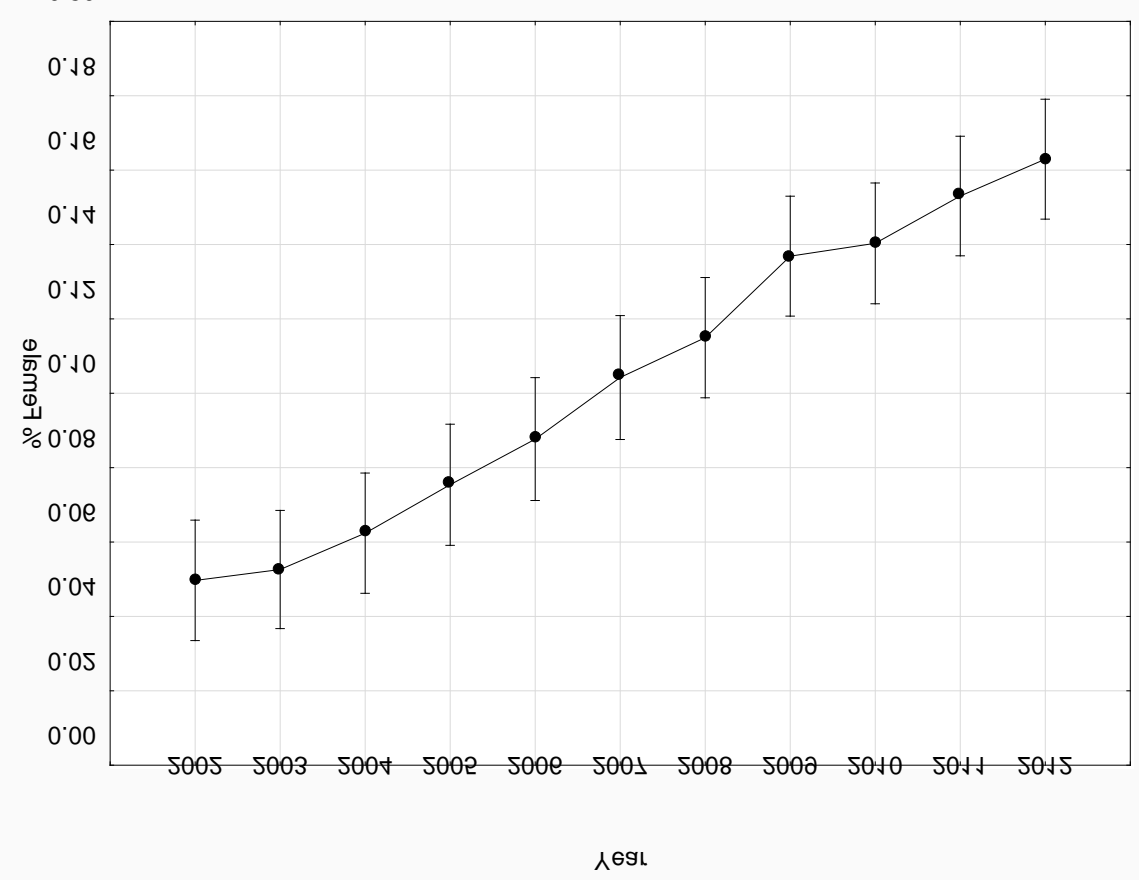

\section{FIGURE 1: Percentage of female directors over time}

Source: Authors' analysis

The high overall level of non-executive female directors in South Africa is in contrast to the situation in the UK, where only a fifth of FTSE100 non-executive directors are women (Farrell, 2014). The industry with the highest representation of female non-executive directors was industrials (36.77\%), followed by consumer services (26.46\%), consumer goods ( $15.40 \%)$, technology $(12.58 \%)$, health care $(5.21 \%)$ and telecommunications $(3.58 \%)$. A study conducted by PWC (2014) in 2013 shows that women represented $16 \%$ of directors in basic materials and $20 \%$ in financials (two of the industries not covered in this study). Research in the South African banking industry revealed that the glass ceiling, considered a myth by many, is in fact still in existence (Mathur-Helm, 2006). The majority of female managers whom Mathur-Helm (2006) interviewed felt that barriers to reaching the top corporate structures are nurtured by organisational culture, policies and strategies. 
TABLE 3: Descriptive statistics: Female directors

\begin{tabular}{|c|c|c|c|c|c|c|c|c|c|}
\hline \multirow{2}{*}{ year } & \multirow{2}{*}{ N } & \multirow{2}{*}{$\begin{array}{c}\text { Mean \% } \\
\text { female } \\
\text { directors }\end{array}$} & \multirow{2}{*}{$\begin{array}{l}\text { Standard } \\
\text { deviation }\end{array}$} & \multirow{2}{*}{$\begin{array}{c}\text { Standard } \\
\text { error }\end{array}$} & \multicolumn{2}{|c|}{ Confidence interval } & \multicolumn{3}{|c|}{ Female directorships } \\
\hline & & & & & $-95.00 \%$ & $+95.00 \%$ & Total & $\%$ FNE & $\% B F$ \\
\hline 2002 & 140 & 5.47 & 9.54 & 0.81 & 3.87 & 7.06 & 1242 & 68.49 & 50.68 \\
\hline 2003 & 150 & 5.59 & 8.54 & 0.70 & 4.21 & 6.96 & 1379 & 66.67 & 50.62 \\
\hline 2004 & 142 & 7.01 & 9.68 & 0.81 & 5.41 & 8.62 & 1288 & 71.74 & 56.52 \\
\hline 2005 & 138 & 8.73 & 10.29 & 0.88 & 7.00 & 10.46 & 1260 & 74.56 & 59.65 \\
\hline 2006 & 131 & 9.86 & 10.59 & 0.93 & 8.03 & 11.69 & 1209 & 76.03 & 65.29 \\
\hline 2007 & 127 & 11.39 & 11.33 & 1.00 & 9.40 & 13.38 & 1164 & 78.83 & 64.96 \\
\hline 2008 & 142 & 11.71 & 10.84 & 0.91 & 9.91 & 13.51 & 1290 & 80.39 & 71.90 \\
\hline 2009 & 144 & 13.68 & 11.64 & 0.97 & 11.76 & 15.60 & 1359 & 80.63 & 70.68 \\
\hline 2010 & 140 & 14.26 & 11.98 & 1.01 & 12.26 & 16.27 & 1319 & 84.77 & 77.16 \\
\hline 2011 & 145 & 15.08 & 12.11 & 1.01 & 13.09 & 17.06 & 1440 & 83.33 & 76.13 \\
\hline 2012 & 143 & 16.16 & 12.75 & 1.07 & 14.05 & 18.27 & 1453 & 84.87 & 76.89 \\
\hline Total & 1542 & & & & & & 14403 & 79.43 & 68.87 \\
\hline
\end{tabular}

Source: Authors' analysis

FNE $=$ Female non-executive

$\mathrm{BF}=$ Black Female

\subsection{Descriptive statistics: black directors}

As shown in FIGURE 2 and TABLE 4, the percentage of black directors also increased significantly over the research period $(F=69.8, p<.001)$.

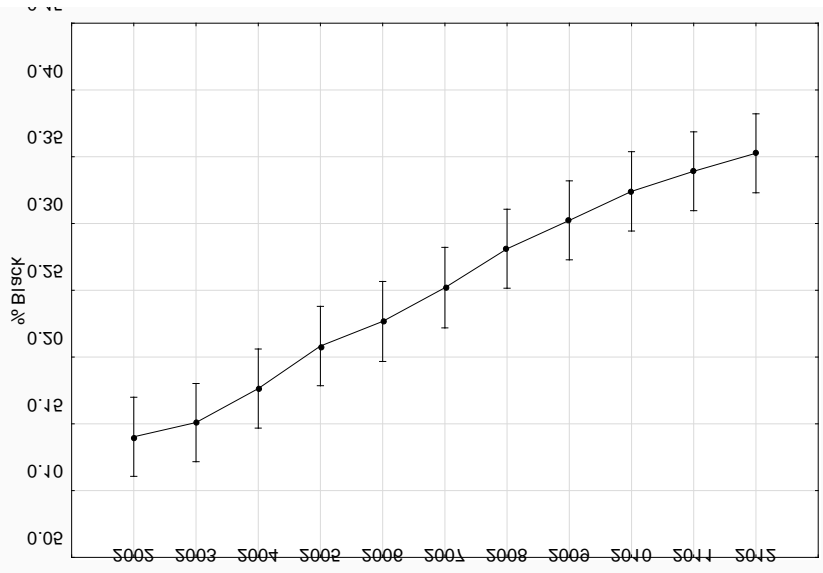

\section{FIGURE 2: Percentage of black directors over time}

Source: Authors' analysis 
TABLE 4: Descriptive statistics: Black directors

\begin{tabular}{llllllllll}
\hline & & & & & \multicolumn{2}{c}{ Confidence interval } & \multicolumn{2}{c}{ Black directorships } \\
\cline { 7 - 9 } Year & $N$ & $\begin{array}{c}\text { Mean } \% \\
\text { black } \\
\text { directors }\end{array}$ & $\begin{array}{c}\text { Standard } \\
\text { deviation }\end{array}$ & $\begin{array}{c}\text { Standard } \\
\text { error }\end{array}$ & & $-95.00 \%$ & $+95.00 \%$ & Total & $\begin{array}{c}\text { \% Black non- } \\
\text { executive } \\
\text { directors }\end{array}$ \\
\hline 2002 & 140 & 13.10 & 16.97 & 1.43 & 10.26 & 15.93 & 1242 & 85.13 \\
\hline 2003 & 150 & 15.44 & 19.16 & 1.56 & 12.35 & 18.53 & 1379 & 82.76 \\
\hline 2004 & 142 & 18.06 & 20.13 & 1.69 & 14.72 & 21.40 & 1288 & 80.80 \\
\hline 2005 & 138 & 21.28 & 21.75 & 1.85 & 17.62 & 24.94 & 1260 & 79.09 \\
\hline 2006 & 131 & 22.27 & 20.53 & 1.79 & 18.72 & 25.82 & 1209 & 81.85 \\
\hline 2007 & 127 & 24.98 & 19.52 & 1.73 & 21.55 & 28.41 & 1164 & 82.94 \\
\hline 2008 & 142 & 27.69 & 20.33 & 1.71 & 24.32 & 31.06 & 1290 & 83.11 \\
\hline 2009 & 144 & 29.09 & 19.82 & 1.65 & 25.82 & 32.35 & 1359 & 85.68 \\
\hline 2010 & 140 & 31.89 & 19.57 & 1.65 & 28.62 & 35.16 & 1319 & 87.09 \\
\hline 2011 & 145 & 32.71 & 19.51 & 1.62 & 29.51 & 35.92 & 1440 & 87.23 \\
\hline 2012 & 143 & 34.00 & 19.71 & 1.65 & 30.74 & 37.26 & 1453 & 87.40 \\
\hline Total & 1542 & & & & & & 14403 & 84.45 \\
\hline
\end{tabular}

Source: Authors' analysis

This finding is in line with Sieren (2012) and Nyirenda (2010). On average, over the 11-year study period, a quarter of board members were blacks. In contrast to the improvement in female nonexecutive board representation, the percentage of black non-executive directors stayed relatively stable over the research period (at around 85\%). Nyirenda (2010) and the 2011 Business Unity South Africa survey also highlighted the fact that most black directors are appointed as non-executive directors.

\subsection{Descriptive statistics: board diversity score}

As illustrated in FIGURE 3, the percentage of companies with 'poor' diversity scores gradually decreased over time, whereas the percentage of companies with 'good' diversity scores increased.

In 2012, close to $10 \%$ of the sample had a 'good' board diversity score, indicating that female and black directors respectively represented more than a third of the companies' overall board structure. A closer look at the annual reports of these companies showed that they view cultural diversity as a source of competitive advantage and have implemented various transformation and mentoring programmes. Although the percentages of average and good board diversity scores have increased over time, much remains to be done to meet the $50 \%$ diversity targets set by the government for 2017 (Ferreira \& De Villiers, 2011). 


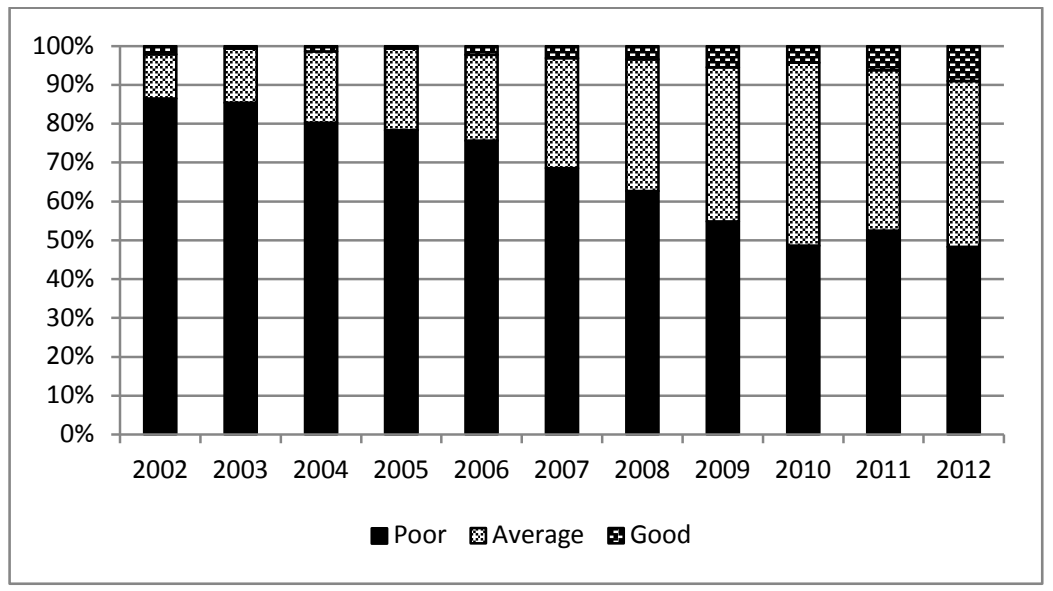

\section{FIGURE 3: Board diversity scores over time}

Source: Authors' analysis

\subsection{Board diversity across industries}

A one-way ANOVA revealed that significant differences existed between industries in terms of female board representation $(F=10.17 ; p=.000)$. The lowest number of female directors served on the boards of companies listed in the consumer goods industry $(8.49 \%)$ and the most in the telecommunications industry (14.83\%). The outcome of the post hoc Scheffé test is shown in TABLE 7 (mean scores are indicated in brackets).

TABLE 7: Significant differences in the percentage of female directors based on industry

\begin{tabular}{|c|c|c|c|c|c|c|}
\hline Industry & $\begin{array}{l}\text { Health } \\
(13.87 \%)\end{array}$ & $\begin{array}{l}\text { Consumer } \\
\text { goods } \\
(8.49 \%)\end{array}$ & $\begin{array}{c}\text { Consumer } \\
\text { services } \\
(12.59 \%)\end{array}$ & $\begin{array}{c}\text { Technology } \\
\text { (13.98\%) }\end{array}$ & $\begin{array}{c}\text { Tele- } \\
\text { commu- } \\
\text { nications } \\
(14.83 \%)\end{array}$ & $\begin{array}{c}\text { Industrials } \\
\text { (9.33\%) }\end{array}$ \\
\hline Health & & 0.063 & 0.987 & 1.000 & 1.000 & 0.141 \\
\hline $\begin{array}{l}\text { Consumer } \\
\text { goods }\end{array}$ & & & $0.001 *$ & $0.000 \star \star$ & 0.083 & 0.960 \\
\hline $\begin{array}{l}\text { Consumer } \\
\text { services }\end{array}$ & & & & 0.885 & 0.939 & 0.001 * \\
\hline Technology & & & & & 0.999 & $0.000 * *$ \\
\hline $\begin{array}{l}\text { Telecommu- } \\
\text { nications }\end{array}$ & & & & & & 0.164 \\
\hline Industrials & & & & & & \\
\hline
\end{tabular}

Source: Authors' analysis

* Significant at the $95 \%$ confidence level $* \star$ Significant at the $99 \%$ level

Companies in the consumer services industry and industrials had significantly more female directors compared to companies listed in the consumer goods industry. Arguden (2012) claims 
that companies with female directors deal more effectively with customers' concerns, as the female directors are often the ones making the purchasing decisions in their households. Female buyers drive $70 \%$ of purchase decisions by consumers in the European Union and $80 \%$ of purchasing decisions in the United States (Arguden, 2012). Companies listed in the technology industry had significantly more female directors than companies operating in the consumer goods and industrial industries. A possible reason is that innovation (resulting from diversity) is highly prized in this industry.

Significant differences were also noted in terms of the percentage of black directors across industries $(\mathrm{F}=20.08 ; p=.000)$ (TABLE 8).

TABLE 8: Significant differences in the percentage of black directors based on industry

\begin{tabular}{|c|c|c|c|c|c|c|}
\hline Industry & $\begin{array}{c}\text { Health } \\
(32.13 \%)\end{array}$ & $\begin{array}{c}\text { Consumer } \\
\text { goods } \\
(17.18 \%)\end{array}$ & $\begin{array}{c}\text { Consumer } \\
\text { services } \\
(25.26 \%)\end{array}$ & $\begin{array}{l}\text { Technology } \\
\text { (29.35\%) }\end{array}$ & $\begin{array}{c}\text { Tele- } \\
\text { commu- } \\
\text { nications } \\
\quad(47.93 \%\end{array}$ & $\begin{array}{l}\text { Industrials } \\
\text { (24.03\%) }\end{array}$ \\
\hline Health & & $0.000 * *$ & 0.346 & 0.977 & $0.023 *$ & 0.145 \\
\hline $\begin{array}{l}\text { Consumer } \\
\text { goods }\end{array}$ & & & $0.000 * \star$ & $0.000 * \star$ & $0.000 * \star$ & $0.001^{*}$ \\
\hline $\begin{array}{l}\text { Consumer } \\
\text { services }\end{array}$ & & & & 0.429 & $0.000 * *$ & 0.971 \\
\hline Technology & & & & & $0.000 * \star$ & 0.093 \\
\hline $\begin{array}{l}\text { Telecommu- } \\
\text { nications }\end{array}$ & & & & & & $0.000 * *$ \\
\hline Industrials & & & & & & \\
\hline
\end{tabular}

Source: Authors' analysis

* Significant at the $95 \%$ confidence level ** Significant at the $99 \%$ level

Once again, the least diversified industry in terms of board race diversity was consumer goods $(17.18 \%)$. This industry's mean score was significantly lower than that of all five of the other industries considered. The industry with the greatest percentage of black directors was once again the telecommunications industry. Black board representation in this industry was significantly higher than the other five considered industries. In South Africa, the telecommunications industry is dominated by the state-owned Telkom (Independent Communications Authority of South Africa, 2014; Chabane, 2010; Department of Public Enterprises, 2002). Accordingly, the directorate of the company more accurately reflects the demographics of the country than non-state-owned companies.

\subsection{Hypothesis testing}

TABLES 9 and 10 present the regression statistics used to test the research hypotheses. In contrast to previous research, no significant relationship was observed between board diversity (in terms of gender and race) and ROA or ROE. However, a statistically significant positive relationship existed between EPS and the percentage of both female and black directors. Based on this finding, hypotheses $\mathrm{H}_{1 \mathrm{a}}$ and $\mathrm{H}_{2 \mathrm{a}}$ were supported. 


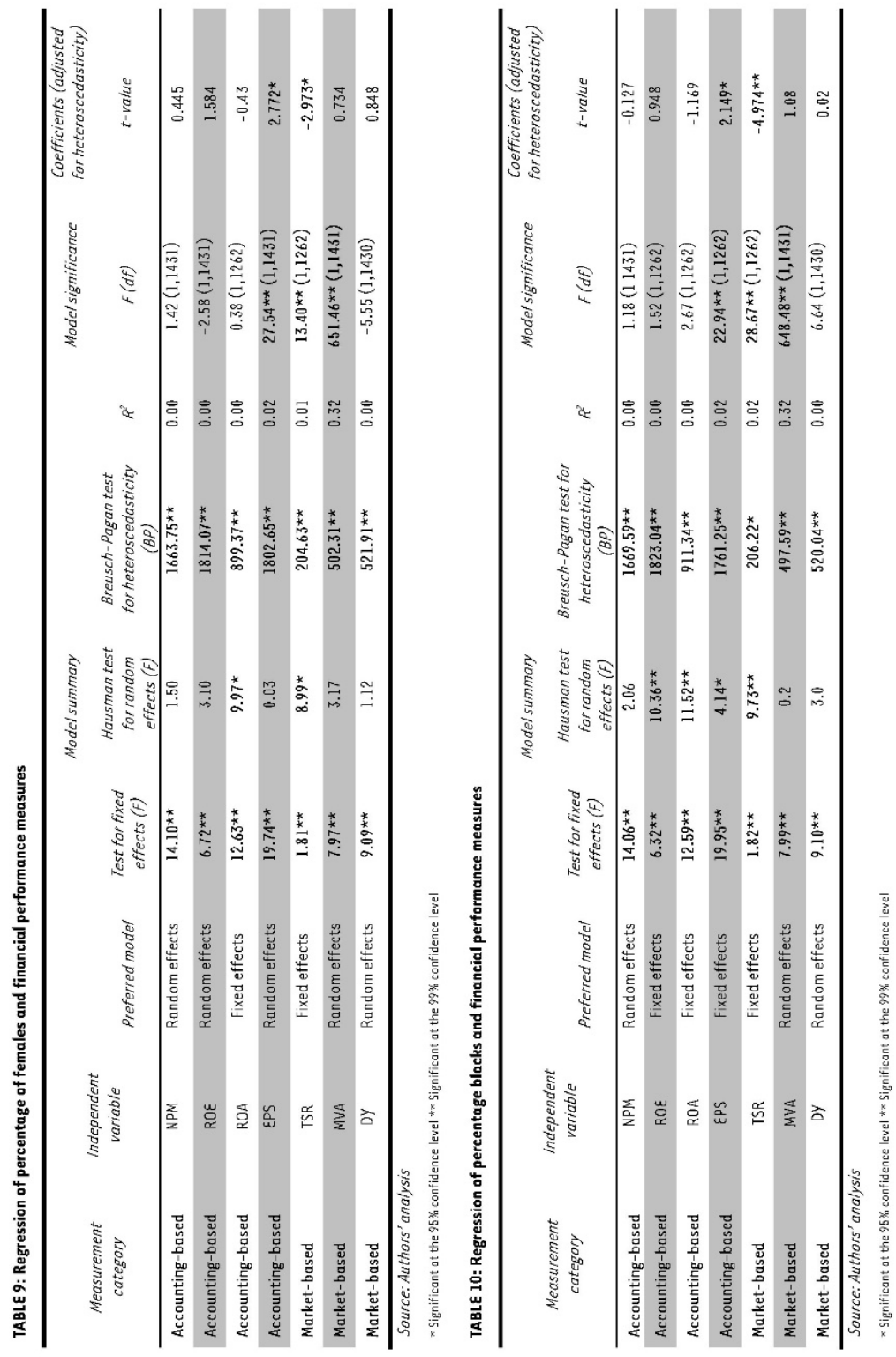


As in the case with the accounting-based measures, only one statistically significant relationship was observed amongst the market-based measures. Here, a significant negative relationship was found between TSR and both measures of board diversity used in this study. This finding implies that the alternative hypotheses $\mathrm{H}_{1 b}$ and $\mathrm{H}_{2 b}$ were also supported. In interpreting this finding, it should be borne in mind that a company's share price could be influenced by a multitude of factors (such as market conditions) and not only the market's perception of its board. This is particularly true during times of financial turmoil (such as the 2007-2009 global financial crisis that formed part of the study period). One possible reason for the negative relationship could relate to the notion of over-boardedness (a term describing directors serving on multiple boards at the same time).

Research shows that such directors can often not give sufficient attention to their corporate and fiduciary duties due to schedule conflict (Harris \& Shimizu, 2004). Fich and Shivdasani (2006) reported that companies' share prices reacted favourably to news of the resignation of 'busy' directors. Shareholders' dissatisfaction with having 'busy' directors on their board could stem from the fact that these directors' independence is compromised due to commitments to other companies. In the Malaysian context, Haniffa and Hudaib (2006) also found a significant negative relationship between multiple directorships and market performance (based on a measure similar to the TSR used in this study). Their findings are in sharp contrast to those of Perry and Peyer (2005), who established that individuals who hold multiple directorships can enhance firm value. The authors argued that 'busy' directors provide cross-pollination of ideas and best practices based on their experience from serving on other boards.

In South Africa, research by the risk solutions firm Inoxico shows that multiple directorships have arisen partly as a result of $B-B B \varepsilon \varepsilon$ deals concluded over the past ten years. They also warn that over-boarded firms have a higher risk of non-compliance with local corporate governance guidelines compared to firms with fewer over-boarded directors (The Inoxico Director Singularity Index, 2013). The existence and impact of over-boardedness on financial performance clearly needs more research within the South African context.

\section{CONCLUSIONS AND RECOMMENDATIONS}

In the introduction, it was argued that a strong business case for diversity could encourage greater transformation of JSE-listed boards. For the purposes of this paper, board diversity was measured only in terms of gender and race, as these two issues are the most pertinent in the board diversity debate in South Africa at present. A review of the literature revealed mixed results on the relationship between board diversity and various measures of financial performance. In this study a combination of accounting-based and market-based performance measures was used to empirically investigate the relationship.

All four of the alternative hypotheses were supported, but the results were contradictory. A positive relationship was found between diversity and accounting-based performance, while a negative relationship was found between diversity and market-based performance. The findings of this study thus do not provide a strong business case for board diversity in South Africa. The business case is further diluted when it is taken into consideration that most female and black directors were appointed as non-executive board members over the research period.

In the light of the above, the question arises as to how true (non-token) board diversity can be encouraged in South Africa. As indicated earlier, the researchers are of the opinion that 
legislation is not the most effective mechanism to encourage change. In line with April, Dreyer and Blass (2007), the researchers feel that a socio-cultural shift is instead required to empower women and blacks to achieve greater equality in the South African corporate environment. A shift in the corporate mentality will also reduce the need for a strong business case for greater board diversity (and other morally-rooted actions such as corporate social responsibility).

Lewis (2004) warned that 'when you are honest only because honesty pays, you risk forgetting the meaning of honesty. When you are responsible only because responsibility pays, you lose any real sense of what responsibility means.' Grosvold, Brammer and Rayton (2007) likewise contend that companies should view diversity as a positive attribute in its own right, rather than a means to an end.

Due to South Africa's history of discrimination, diverse board members often do not have the necessary skills, but acquire them only in the process of their board membership (Prinsloo \& Shevel, 2013). The IoDSA thus undertakes effort to develop, mentor, coach and educate directors. In the second King Report, companies are urged to extend their mentoring programmes for inexperienced directors, since guidance by an experienced director can clarify the board's dynamics for new and inexperienced board members (IoDSA, 2002). Business Unity South Africa (2010) also suggests that companies develop and implement (more) measures to overcome under-representation by females and blacks on corporate boards.

Business Unity South Africa (2010) furthermore recommends that female and black mentees be appointed as 'shadow' directors. Such shadow directors should then be mentored by directors who will retire within 18 months. If the mentee's progress is sufficient, he or she can then replace the retired mentor director. Diverse talent should be constantly developed and mentored in order to ensure that there is a larger selection of candidates available for future board positions.

Further research is required into the nature of the relationship between board diversity and market-based performance measures on the JSE (especially total shareholder return). The insights of sociologists might be valuable to consider the social behaviour of investors regarding firms' diversity (or the lack thereof). It is further suggested that a follow-up study be conducted a decade from now to see whether educational interventions have paid off for the generation born after 1994. The expectation is that post-1994 educated individuals could lead a new diverse era for corporate South Africa. Attention could also be given to variables such as the size of the board, the age of directors and board tenure in future studies. Board leadership and the role of black female directors could also be investigated in more depth. Only when we as South Africans find a way to celebrate our diversity will we be able to find strength in our differences in the business community.

\section{Acknowledgements}

The authors would like to thank Mr Gerrit Marais and Ms Samantha Mitchell for their assistance with the data capturing and Prof Martin Kidd for his assistance with the statistical analysis. 


\section{LIST OF REFERENCES}

Abdo, A. \& Fisher, G. (2007). The impact of reported corporate governance disclosure on the financial performance of companies listed on the JSE. Investment Analysts Journal, 66(1), pp. 43-54.

Adams, R.B. \& Ferreira, D. (2009). Women in the boardroom and their impact on governance and performance. Journal of Financial Economics, 94(1), pp. 291-309.

April, K., Dreyer, S. \& Blass, E. (2007). Gender impediments to the South African executive boardroom. South African Journal of Labour Relations, 31(2), pp. 51-67.

Arguden, Y. (2012). Why boards need more women. Harvard business review, 7 June. Available: http://blogs.hbr.org/2012/06/why-boards-need-more-women/. (Accessed 24 February 2014).

Brigham, E.F. \& Houston, J.F. (2012). Fundamentals of Financial Management, $t^{\text {th }}$ edition. Mason: Thomson.

Bromley, V.L. (2012). Feminisms matter: debates, theories, activism. Ontario: University of Toronto Press.

Bureau for Economic Research. (2009). Economic activity expected during 2009 and 2010. Economic Prospects, 24(2), pp. 1-34.

Business Unity South Africa. (2011). Business Unity South Africa transformation study. A snapshot of the demographic profile and pace of transformation of JSE-listed companies. Available: http://busa.org.za/press-releases/. (Accessed 2 March 2014).

Business Unity South Africa. (2010). Media statement: expediting transformation and succession planning in corporate $S A$. Available:

http://www.busa.org.za/docs/BUSA\%20Statement\%20\%20Expediting\%20Transformation\%20in\%20C orporate\%20SA.pdf. (Accessed 28 May 2011).

Campbell, K. \& Minguez-Vera, A. (2008). Gender diversity in the boardroom and financial performance. Journal of Business Ethics, 83(3), pp. 435-451.

Carter, D.A., D'Souza, F.D., Simkins, B.J. \& Simpson, G.W. (2010). The gender and ethnic diversity of US boards and board committees and firm financial performance. Corporate Governance: an International Review, 18(5), pp. 396-414.

Carton, R.B. \& Hofer, C.W. (2006). Measuring organizational performance: metrics for entrepreneurship and strategic management research. Cheltenham: Edward Elgar.

Chabane, C. (2010). Statement by Minister Collins Chabane on the terms of reference and review framework and methodology of the presidential state owned enterprises review committee. Cape Town, 12 0ctober. Available: http://www.pmg.org.za/briefing/20101012-min-chabane-ministerpresidency-performance-monitoring-and-evaluation. (Accessed 13 February 2014).

Chorafas, D.N. (2005). The management of equity investments: capital markets, equity research, investment decisions and risk management with case studies. Amsterdam: Elsevier ButterworthHeinemann.

De Jager, J. (2008). Panel data techniques and accounting research. Meditari Accountancy Research, 16(2), pp. 53-68.

Department of Public Enterprises. (2002). Protocol on corporate governance in the public sector. Available: http://www.info.gov.za/view/DownloadFileAction?id=70233. (Accessed 24 June 2013). 
Dobbin, F. \& Jung, J. (2011). Corporate board gender diversity and stock performance: the competence gap or institutional investor bias? North Carolina Law Review, 89, pp. 809-939.

Dutta, P. \& Bose, S. (2007). Gender diversity in the boardroom and financial performance of commercial banks. Evidence from Bangladesh. The Cost and Management, 34(6), pp. 70-74.

Dwyer, L., Gill, A. \& Seetaram, N. (2012). Handbook of research methods in tourism: quantitative and qualitative approaches. Cheltenham: Edward Elgar Publishing.

Early, P.C. \& Mosakowski, દ. (2000). Creating hybrid team structures: An empirical test of transformational team functioning. Academy of Management Journal, 11(1), pp. 102-111.

Erhardt, N.L., Werbel, D. \& Shrader, C.B. (2003). Board of director diversity and firm financial performance. Corporate Governance: an International Review, 11(2), pp. 102-111.

European Commission. (2012). Implementation checklist for diversity management: support for voluntary initiatives promoting diversity management at the workplace across the $\varepsilon U$. Available: http://ec.europa.eu/justice/discrimination/files/checklist_diversitymanagement_en.pdf. (Accessed 18 February 2014).

Fama, E.F. \& Jensen, M.C. (1983). Separation of ownership and control. Journal of Law and Economics, 26(1), pp. 301-325.

Farrell, S. (2014). Women in the boardroom: non-exec jobs may be best, says Lord Davies. The Guardian, 22 January. Available: http://www.theguardian.com/world/2014/jan/22/women-in-theboardroom-non-exec-jobs. (Accessed 24 January 2014).

Ferreira, P. \& De Villiers, C. (2011). The association between South African listed companies' BEE scores and market performance: an introductory study. Meditari Accountancy Research, 19(1/2), pp. 22-28.

Fich, E.M. \& Shivdasani, A. (2006) Are busy board effective monitors? Journal of Finance, 61(2), pp. 689-724.

Government Gazette. (2004). No. 53 of 2003: Broad-Based Black Economic Empowerment Act, 2003. Vol. 463, No. 25899. Available: http://www.info.gov.za/view/DownloadFileAction?id=68031. (Accessed 6 September 2012).

Grobler, P.A., Wärnich, S., Carrell, M.R., Elbert, N.F. \& Hatfield, R.D. (2006). Human Resource Management in South Africa, $3^{\text {td }}$ edition. London: Thompson Learning.

Gross, K. (2007). Equity ownership and performance: an empirical study of German traded companies. Heidelberg: Physica.

Grosvold, J., Brammer, S. \& Rayton, B. (2007). Board diversity in the United Kingdom and Norway: an exploratory analysis. Business Ethics: a European Review, 16(4), pp. 344-357.

Haniffa, R. \& Hudaib, M. (2006). Corporate governance structure and performance of Malaysian listed firms. Journal of Business Finance \& Accounting, 33(788), pp. 1034-1062.

Harris, I.C. \& Shimizu, K. (2004). Too busy to serve? An examination of the influence of overboarded directors. Journal of Management Studies, 41(5), pp. 775-798.

Hart, S.L. \& Milstein, M.B. (2002). Creating sustainable value. Academy of management perspective, $17(2)$, pp. 56-67.

Hassett, M.E. \& Paavilainen-Mäntymäki, દ. (2013). Handbook of longitudinal Research Methods in Organisations and Business Studies. Cheltenham: Edward Elgar Publishing. 
Hayes, A.F. \& Cai, L. (2007). Using heteroskedasticity-consistent standard error estimates in OLS regression: an introduction and software implementation. Behavior Research Methods, 39 (4), pp. 709-722.

Huse, M. (2007). Boards, governance and value creation. Cambridge: Cambridge University Press. Independent Communications Authority of South Africa. (2014). Telkom. Available: http://ictindicatorportal.icasa.org.za/Portal/index.php?p=52. (Accessed 13 February 2014). Institute of Directors in Southern Africa. (2009). King Report on Corporate Governance for South Africa - 2009. Johannesburg: IoDSA.

Institute of Directors in Southern Africa. (2002). King Report on Corporate Governance for South Africa-2002. Johannesburg: IoDSA.

International Financial Reporting Standards. (2012). IAS 33 earnings per share. Available: http://www.ifrs.org/Documents/IAS33.pdf. (Accessed 13 March 2013).

Jianakoplos, N. \& Bernasek, A. (1998). Are women more risk averse? Economic Inquiry, 36(4), pp. 620 630.

Johannesburg Stock Exchange. (2009). ICB structure enhancements effective 30 November 2009. Available: http://www.jse.co.za/Products/FTSE-JSE/Classification-System.aspx. (Accessed l December 2011).

Kacapyr, દ. (2011). Introductory econometrics for undergraduates: a student's guide to the basics. New York: M.E. Sharpe.

Kohler, U. \& Kreuter, F. (2005). Data analysis using Stata. College Station: Stata Press.

Lau, D. \& Murringham, K. (1998). Demographic diversity and fault lines: the compositional dynamics of organizational groups. Academy of Management Review, 23, pp. 240-325.

Lewis, M. (2004). The irresponsible investors. The New York Times, 6 June, Available: http://www.nytimes.com/2004/06/06/magazine/the-irresponsibleinvestor.html? pagewanted $=$ all\&src $=$ pm (accessed 29 0ctober 2013).

Martin, J.D., Petty, J.W. \& Wallace, J.S. (2009). Value-based management with corporate social responsibility, $2^{\text {nd }}$ edition. 0xford: Oxford University Press.

Mathur-Helm, B. (2006). Women and the glass ceiling in South African banks: an illusion or reality? Women in Management Review, 21(4), pp. 311-326.

McGregor BFA (Pty) Ltd. (2014). Research domain. Software and database. Johannesburg.

Mid-year population estimates 2013. (2013). Statistics South Africa. Available:

http://beta2.statssa.gov.za/publications/P0302/P03022013.pdf. (Accessed 13 February 2014).

Miller, T. \& Triana, M.C. (2009). Demographic diversity in the boardroom: Mediators of the board diversity-Firm performance relationship. Journal of Management Science, 46(5), pp. 755-786.

Monks, R.A.G. \& Lajoux, A.R. (2011). Corporate valuation for portfolio investment: analyzing assets earnings, cash flow, stock price, governance, and special situations. New Jersey: John Wiley \& Sons.

Moyer, R.C., McGuigan, J.R. \& Kretlow, W.J. (2009). Contemporary Financial Management, $11^{\text {th }}$ edition. Mason: South-Western Cengage Learning. 
Mtshali, N. (2013). Only 15\% of SA university students graduate. The Star, 13 June. Available: http://www.iol.co.za/lifestyle/family/kids/only-15-of-sa-university-students-graduate1.1531809. (Accessed 15 February 2014).

Mulsow, R. (2011). The relationship between project-portfolio success and multi-dimensional business success. an analysis based on empirical multi-project management study. Diploma thesis, Technical University of Berlin.

Murray, A.I. (1989). Top management group heterogeneity and firm performance. Strategic Management Journal, 10(1), pp. 125-141.

Naidoo, R. (2009). Corporate governance: an essential guide for South African companies, $2^{\text {nd }}$ edition. Durban: LexisNexis.

Natsan, P. (2012). Diversity in the boardroom: a business imperative. Accountancy SA. Available: http://www.accountancysa.org.za/resources/ShowltemArticle. asp? Articleld=2488\&lssue=1118. (Accessed 23 February 2013).

Nyirenda, M. (2010). Board composition in companies listed on the Johannesburg stock exchange. Unpublished Masters Dissertation. Pretoria: University of Pretoria.

Orlando, R.C. (2000). Racial diversity, business strategy and firm performance: A resource based view. Academy of Management Journal, 43(2), pp. 164-177.

Pappaya, M. (2007). South African Newsroom still male dominated. Career Alliance, August, p 4.

Parsons, P.J. (2004). Ethics in Public Relations: A Guide to Best Practice. London: Kogan Page.

Pelled, L.H., Eisenhardt, K.M. \& Xin, K.R. (1999). Exploring the black box: an analysis of work group diversity, conflict, and performance. Administration Science Quarterly, 44(1), pp. 1-28.

Perry, T. \& Peyer, U. (2005). Board seat accumulation by executives: a shareholder perspective. Journal of Finance, 60(4), pp. 2083-2123.

Prinsloo, L. \& Shevel, A. (2013). Not enough talent for SA's boards. Business Day, 3 March. Available: http://www.bdlive.co.za/business/2013/03/03/not-enough-talent-for-sa-s-boards. (Accessed 3 March 2014).

PWC. (2014). Non-executive directors' practices and fees trends report. Available:

http://www.pwc.co.za/en_ZA/za/assets/pdf/ned_report_january_2014.pdf. (Accessed 24 February 2014).

Robinson, G. \& Dechant, K. (1997). Building a business case for diversity. Academy of Management Executive, 11(3), pp. 21-31.

Rose, C. (2007). Does female board representation influence firm performance? The Danish evidence. Corporate Governance: an International Review, 15(2), pp. 404-413.

Rushin, L.T. (2006). The impact on the financial performance of organizations listed on the industrial sector of the JSE. Unpublished Master's of Business dissertation. Pretoria: University of Pretoria.

Scholtz, A. (2014). Women empowerment \& gender equality bill: are there claws in the clauses? Business Brief, February/March, pp. 40-41.

Sieren, A. (2012). The top dogs in black business. Business Day, 18 November. Available: http://www.bdlive.co.za/business/2012/11/18/the-top-dogs-in-black-business. (Accessed 3 March 2014). 
Smith, N., Smith, V. \& Verner, M. (2006). Do women in top management affect firm performance? A panel study of 2,500 Danish firms. International Journal of Productivity and Performance Management, 55(7), pp. 569-593.

South African History Online. (2014). Statement at the meeting of the special committee against Apartheid in observance of the International Day of Solidarity with the struggle of women in South Africa and Namibia, 11 August 1981. Available: http://www.sahistory.org.za/article/mrs-gertrudeshope. (Accessed 2 March 2014).

South African Institute for Chartered Accountants. (2009). Headline earnings. Available: http://www.jse.co.za/Libraries/JSE_Listing_Requirements_\%E2\%80\%93_JSE_Circulars_issued_by_SA ICA/03_Circular_3.sflb.ashx. (Accessed 13 March 2013).

South African Reserve Bank. (2013). Quarterly bulletin, no 270. Available: http://www.resbank.co.za/Publications/QuarterlyBullitins/Pages/QuarterlyBulletins-Home.aspx. (Accessed 27 February 2014).

Stephenson, C. (2004). Leveraging diversity to maximum advantage: The business case for appointing more women to boards. Ivey Business Journal, 1(1), pp. 1-5.

The Inoxico Director Singularity Index. (2013). Inoxico. Available:

http://www.ey.com/Publication/vwLUAssets/The_Inoxico_Director_Singularity_Index__2013_Research_Report/\$FILE/Innoxico.pdf. (Accessed 6 December 2013).

Trautman, L.J. (2008). Boardroom diversity: why it matters. Available: http://www.calpersgovernance.org/docs-sof/marketinitiatives/resources/why-it-matters.pdf. (Accessed 23 February 2013).

Van der Walt, N.T. \& Ingley, C. (2003). Board dynamics and the influence of professional background, gender and ethnic diversity of directors. Corporate Governance: an International Review, 11 (3): 218 234.

Wachudi, ع. \& Mboya, J. (2009). Effect of board gender diversity on the performance of commercial banks in Kenya. European Scientific Journal, 8(7), pp. 128-148.

Watson, W. E., Kumar, K. \& Michaelsen, L.K. (1993). Cultural diversity's impact on interaction process and performance: Comparing homogeneous and diverse task groups. Academy of Management Journal, 36(1), pp. 590-602.

Wixley, T. \& Everingham, G. (2005). Corporate Governance. Claremont: Siber Ink.

Women on boards: a statistical review by country, region, sector and market index. (2009).

Governance metrics international. Available:

http://www.gmiratings.com/(bnnl3555sqbsvh55lv2jfs55)/hp/Women_on_Boards__A_Statistical_Review_from_GMI_-_3_2_09.pdf (Accessed 11 April 2013).

World Federation of Exchanges. (2014). Available: http://www.worldexchanges.org/statistics/annual-query-tool. (Accessed 13 February 2014). 